\title{
Enhancing Creative Problem Solving in Postgraduate Courses of Education Management Using Project-Based Learning
}

\author{
Pengfei Chen ${ }^{1} \&$ Yuan Cheng Chang ${ }^{1}$ \\ ${ }^{1}$ CHINA-ASEAN International College, Dhurakij Pundit University, Thailand \\ Correspondence: Yuan Cheng Chang, CHINA-ASEAN International College, Dhurakij Pundit University, 110/1-4 \\ Prachachuen Road, Laksi, Bangkok 10210, Thailand.
}

Received: April 22, 2021

Accepted: May 21, 2021

Online Published: May 31, 2021

doi:10.5430/ijhe.v10n6p11

URL: https://doi.org/10.5430/ijhe.v10n6p11

\begin{abstract}
The aim of this study is to enhance students' creative problem-solving ability using a project-based learning approach. The study was based on a quasi-experimental design and the participants were 69 postgraduate students in the field of education management. There were 35 of the students assigned to the experimental group, and the remaining 34 to the control group. The experiment was conducted over 15 classes for 2 months. A creative problem-solving questionnaire was used as a pre-test and post-test before and after the experiment. The results showed that the students' creative problem-solving ability had been effectively enhanced by the intervention of project-based learning, especially in terms of identifying problems, finding solutions and evaluating them.
\end{abstract}

Keywords: creative problem solving, postgraduate students, education management, project-based learning

\section{Introduction}

Higher education should play a key role in the process by equipping individuals with the critical skills needed to comprehend the complexity of environmental, social and economic problems and the ability to engage independently and cooperatively in finding a solution (Munyai, 2016). All universities should ensure that their graduates are equipped with the key abilities of critical thinking, communication, problem-solving, research, and teamwork skills to enable them to respond to the constantly-changing needs of society as 'Citizen Scholars' (Arvanitakis \& Hornsby, 2016). It is essential for graduates to possess problem-solving skills to confront a world with a fast-shifting workforce based on global partnerships and digital transformation (Klegeris et al., 2016; Meo, 2014; Bonikowska et al., 2008). The contribution of the field of educational administration and educational management is particularly significant in developing students' knowledge and skills of educational leadership (Chen et al., 2020; García-Martínez et al., 2018). Since a creative problem-solving ability is a crucial characteristic of educational leaders, who are invariably faced with complex, unique and open-ended situations, they are deliberately trained to develop these problem-solving skills (Visone, 2018). Hence, it is essential for education management to focus on advancing postgraduates' problem-solving ability to support the future workforce (Chen et al., 2020).

Professional problem solvers are receiving new requests in relation to creative problem solving (CPS) connected to complex digital-based situations in collaboration with stakeholders of team members, facilitator and clients. In this context, it is significant to teach students any knowledge and skills along with attitudes that can support and facilitate the process of creative and participative problem solving, to complement the traditional perception of this skill (Vidal, 2009). Teachers can assist students to develop problem-solving strategies (Ayers, 1989) and, since thinking does not just occur, but needs to be trained and practiced, all students must be able to develop their creative problem-solving ability by means of teaching, support and practice (Beyer, 1987).

Higher education must provide a challenging, but supportive, learning environment for students with various academic needs (Larkin \& Richardson, 2013). It is essential to be aware of their diversity and how to engage them when preparing a programme or course (Pinho-Lope \& Macedo, 2014). Effective learning involves active learning by doing, cooperating and engaging in teamwork to solve problems (Nordstrom \& Korpelainen, 2011). Project-based learning (PBL) is composed of courses and programmes designed to help students to develop these skills. They learn by participating in projects based on authentic circumstances in which they use the subject matter to solve complex problems in relation to the particular professional for which they are being trained (Chiang \& Lee, 2016; Hârtescu, 2014). Pinho-Lope and Macedo (2014) proved that PBL effectively enhanced college students' problem solving and 
higher older thinking skills through research experiment.

Postgraduate students in the education management field are trained to be educational leaders in the future workforce in the context of sustainability (Chen et al, 2020); hence, they must be able to solve complex problems creatively a world that is rapidly changing due to digital transformation. Hence, the aim of this study is to develop master students' creative problem-solving skills in an education management postgraduate course using project-based learning. The course consisted of a quasi-experimental intervention with a PBL design to enhance students' CPS abilities. Two research questions were examined. The first whether or application of PBL could effectively enhance postgraduate students' CPS in an education management course, while the second was which key skills of CPS had significantly improved after the experiment.

\section{Theory}

Since this study was based on the application of PBL to develop postgraduate students' CPS, the theories of CPS and PBL are explained below.

\subsection{Creative Problem Solving (CPS)}

Puccio et al. (2007) define CPS as an effective system of comprehensive cognition built on an inherent creative process that consciously ignites creative thinking and, as a result, produces creative solutions and change. CPS is the process of deliberately inducing the kind of thinking that is required to effectively solve complex problems (Puccio \& Cabra, 2008). Many models have evolved since Osborn (1953) proposed the idea of CPS and, a decade later, he introduced a three-step model of fact-finding, idea finding and solution finding (Osborn, 1963), which Parnes (1967) extended to a five-step model of fact-finding, problem-finding, idea-finding, solution-finding and acceptance-finding. Subsequently, Isaksen and Treffinger (1985) added a sixth step of mess-finding, and nine years later, they added three more steps, namely, understanding the problem, idea generation, and planning for action (Isaksen et al., 1994). Subsequently, Isaksen et al. (2000) updated the model again with planning your approach (appraising tasks and designing process), understanding the challenges (constructing opportunities), understanding the challenges (exploring data), understanding the challenges (framing problems), generating ideas, preparing for action (developing solutions), and preparing for action (building acceptance).

Puccio et al. (2007) integrated all of these historical models and the new features of the CPS framework into three main categories of the thinking model, which they labelled "Clarification, Transformation and Implementation" (Puccio \& Cabra, 2008, p. 331). Each of these three categories includes two CPS steps. The Clarification stage involves assessing the situation, clarifying the vision to explore, and identifying the challenges. The Transformation stage involves exploring ideas and planning a solution, while the last stage, Implementation, involves accepting the solution and making a plan to put it into action (Puccio et al., 2007). Haynes (1989) also added to the four stages of problem solving with identifying the problem, representation of problem, planning the solution, execute the plan, evaluating the plan, and evaluating the solution. Therefore, in their empirical research, Laio et al. (2014) proposed a model with five steps, which consisted of identifying problems, defining problems, finding solutions, evaluating the solution, and implementing the plan. This is the model that was used in this research to evaluate postgraduate students' problem-solving abilities before and after the intervention.

\subsection{Project-Based Learning (PBL)}

Project-based learning is an approach that requires the active engagement of students and consists of diverse collaborative, inquiry-based learning, and inductive learning (Loyens, et al., 2010). PBL is learning by becoming immersed in a project. Students are presented with an authentic situation and invited to explore the subject matter and use their findings to solve complex problems in relation to the profession for which they are being trained (Tsybulsky \& Muchnik-Rozanov, 2019; Hârtescu, 2014). They are divided into groups to examine the problems in order to shape their knowledge via collecting and analysing data, evaluating, organising and discussing to develop their cognitive and critical thinking skills (Wu \& Wu, 2020; Fleming, 2000; Krajcik et al. 1994). In a PBL environment, students primarily learn by constructing knowledge and making meaning through an iterative process that involves questioning, active learning, sharing and reflection (Chiang \& Lee, 2016). This transdisciplinary, learner-centered and collaborative process focuses on educational opportunities integrated with real-life matters and preparation to face real-world challenges (English \& Kitsantas, 2013). This is an efficient approach which is commonly applied in diverse classroom settings (Thomas \& Mergendoller, 2001).

In implementing the project activities, students are required to complete the tasks they can manage and are trained to work in a group, where it is significant to listen to partners, and agree or disagree with them; in other words, provide arguments to support one's belief. Students begin to sense that they are contributing to a group project that will not 
only deliver specific knowledge through real-world practice, but also enable them to develop their capabilities and skills (Bolsunovskaya et al., 2015). Therefore, PBL is an effective teaching approach to develop $21^{\text {st }}$ century skills such as critical thinking and problem solving, interpersonal communication, collaboration, teamwork, leadership, creativity and innovation, and information and media literacy (Tsybulsky \& Muchnik-Rozanov, 2019; Chu et al., 2017; Häkkinen et al., 2017). Pinho-Lopes and Macedo (2014) proposed the five-step model of project-based learning applied to the experiment in this study. It consists of traditional lectures (to present the significant concepts), practical lessons (practice to solve problems connected to each aspect of the syllabus), compulsory team projects, oral presentations and discussion sessions, and individual marks on the team projects (using the learners' self and peer evaluation).

\section{Methods}

This study was based on a quasi-experimental design with a non-equivalent control group and its aim was to enhance creative problem solving in a postgraduate course of education management. The participants were 69 postgraduate students in the field of education management (Note 1) who were randomly assigned to an experimental class and a control class. The independent variable was problem-based learning and the dependent variables were a pre-test and a post-test to evaluate the postgraduates' CPS. The control variables were teaching time and contents.

\subsection{Participants}

This research was conducted in a private university in Bangkok, Thailand. There were 69 master students in the programme of education management participated in the study. Thirty-five of them were allocated to the PBL intervention as the experimental group (EG), which the remaining 34 were assigned to the control group (CG). These two groups took the regular education management courses with different teaching means. The EG were taught using PBL, while the CG's learning was lecture-based. In total, there are 27 male students and 42 females; hence, the gender ratio was approximately $4: 6$.

\subsection{Research Intervention}

The PBL intervention to develop the CPS of the students in the EG was implemented in 15 classes over 2 months, 3-hour classes per week by the researcher. The objective of these classes was to enhance the students' understanding, skills and research capabilities in relation to education management and Bloom's Taxonomy (Anderson et al., 1994) was used for the teaching, especially of higher-order cognitive abilities with application, analysis, synthesis and evaluation, to demonstrate a deeper comprehension of the material. The five-step model of PBL by Pinho-Lopes and Macedo (2014) was mainly applied to the instruction, and the process of the PBL experiment, which consisted of two phases, is shown in Figure 1. Phase one, which consisted of the $1^{\text {st }}$ to the $5^{\text {th }}$ classes, began with an explanation of the course objectives. This was followed by a pre-test of the CPS of both the EG and CG students before forming the groups. In total, there were seven small teams with five to six members per team. The last step of phase 1 was to input the fundamental theory and knowledge related to education management and provide techniques to plan the team projects in phase two. Each project needed a topic based on the main theme of admitting and recruiting students' and each team needed to define a theme-related topic. The seven topics defined by the seven teams are shown in Table 1.

After determining the topics, the teams were required to investigate the needs and requests from the customers and plan the contents. In other words, the project started by determining the objectives based on a literature review and then progressed with a marketing investigation and evaluation. Next, the team members needed to discuss and assess all the information and content plan, as well as report their progress. The final step involved a presentation, and individual peer and expert evaluations were applied to assess the project. At the end of phase two, the CPS of both the EG and the CG was subjected to a post-test. 


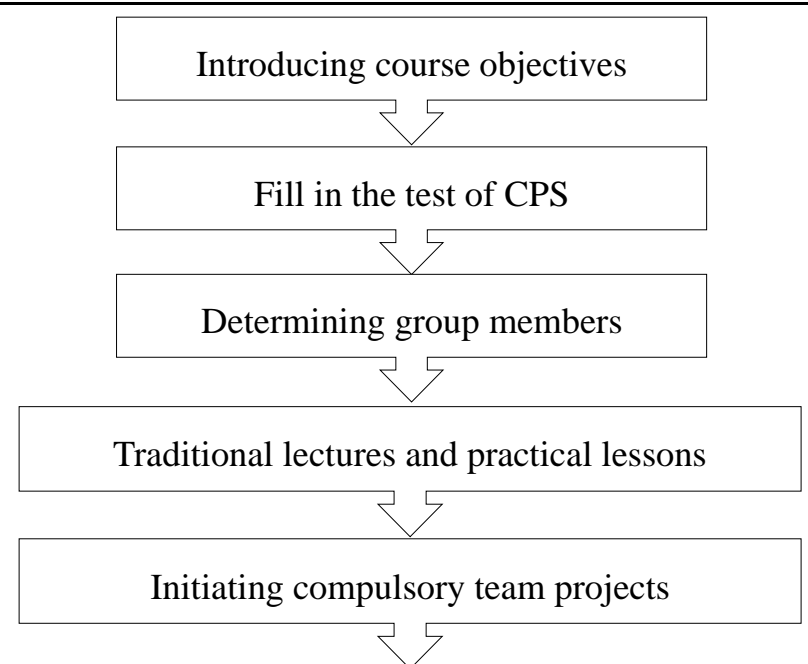

Phase 1

Classes 1-5

Phase 2

Classes 6-15

Oral presentations and discussion sessions: topic, objectives, literature review, investigate the needs of customers, content planning, synthesizing information, reporting the project

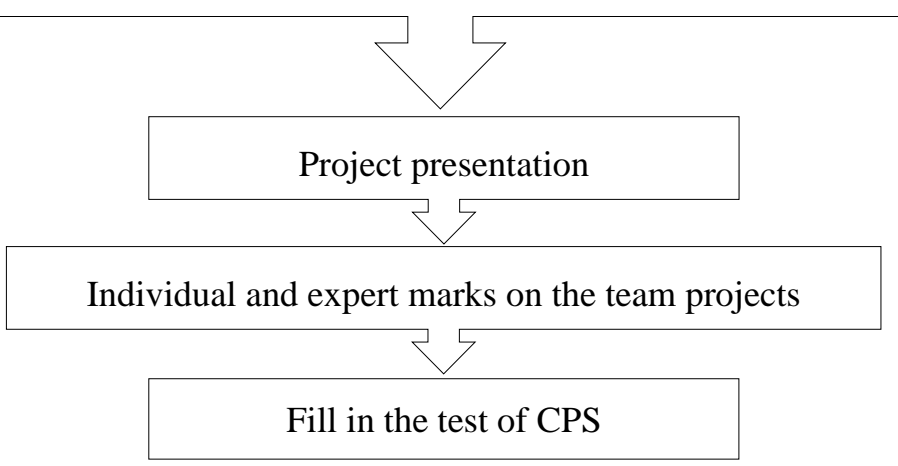

Figure 1. Procedure of the PBL intervention

Table 1. Projects' topics of the 7 teams

\begin{tabular}{cl}
\hline Teams & \multicolumn{1}{c}{ Projects' topics } \\
\hline 1 & Travelling enrich one's knowledge and broaden one's horizon \\
3 & As alumni, fortunate for three lifetimes \\
4 & Bring in, Going out \\
5 & Meet you again in the place where "Gardenia blooms" \\
6 & One Belt Culture, All the Way Style \\
7 & Learning Targets are more than a road
\end{tabular}

In the context of equivalent timescales and teaching content, the CG students did not receive any specific instructions, but an active control group was included in the study with the aim of assessing progress based on parallel variance motivation, expectations and the placebo effect (Chen et al., 2017; Zhang et al., 2019; Chen et al., 2020). The CG attended 15 classes over 2 months ( 2 x 3-hour classes every week). The teaching content was as relevant to educational management as the content delivered to the EG, but PBL was not applied and the teaching was lecture-based and teacher-centred.

\subsection{Creative Problem-Solving Questionnaire (CPSQ)}

The CPSQ was used as a pre-test and post-test in this study to examine the participants' creative problem solving before and after the research intervention. Laio et al. (2014) constructed the CPSQ when they conducted a teaching experiment to enhance college students' CPS. The factors of the CPSQ used in this study were identifying problems 
with 9 items $(\alpha=.876)$, defining problems with 3 items $(\alpha=.707)$, finding solutions with 5 items $(\alpha=.738)$, evaluating the solution with 5 items $(\alpha=.725)$, and implementing the plan with 4 items $(\alpha=.736)$. The questionnaire contained a total of 26 items set on a 5-point Likert scale from $1=$ Strongly disagree to $5=$ Strongly agree. The alpha coefficient of the five parts had a relatively high internal consistency.

\section{Results}

All 69 postgraduate students of education management in both the EG and the CG were subjected to the CPSQ pre-test and post-test. There were 35 valid respondents in the experimental group (100\%) and 34 in the control group $(100 \%)$, making a total of 69 valid respondents, as shown in Table 2 . There were 14 male and 21 female students in the EG and 16 male and 22 female students in the CG. In terms of the result of the post-test, there was no significant difference between genders in both the EG $(t=-.052, p>.05)$ and the CG $(t=-1.384, p>.05)$, which indicated that the instructional methods had not had a different effect on both genders of master students.

Table 2. Descriptive analysis of the participants

\begin{tabular}{cccc}
\hline Groups & Gender & N & Valid response \\
\hline \multirow{2}{*}{ EG } & Male & 14 & $35(100 \%)$ \\
& Female & 21 & \\
\multirow{2}{*}{ CG } & Male & 13 & $34(100 \%)$ \\
& Female & 21 & \\
\hline
\end{tabular}

\subsection{Paired Sample T-Test}

A paired sample t-test was applied to assess the CPS of the students in the experimental group after the PBL intervention. As can be seen from Table 3, these students' CPS had increased significantly $(p<.001)$ in the dimensions of identifying problems, finding solutions and implementing the plan. This was a clear indication of the ability of PBL to enhance college students' CPS. The post-test score of these students was significantly higher than it was in the pre-test. In contrast, there was no significant difference in the pre-test and post-test score of the students in the CG, which was proof that the lecture-based approach had not succeeded in enhancing the students' CPS after 15 lessons.

Table 3. Summary of the paired sample $t$-test to the EG

\begin{tabular}{|c|c|c|c|c|c|}
\hline Factors & Groups & Tests & Mean & SD & $t$ \\
\hline Creative Problem & \multirow{12}{*}{ EG } & Pre-test & 3.800 & .666 & $-2.032 *$ \\
\hline Solving (CPS) & & Post-test & 3.971 & .617 & \\
\hline \multirow{2}{*}{$\begin{array}{l}\text { Identifying } \\
\text { problems }\end{array}$} & & Pre-test & 3.742 & .780 & $-2.400^{*}$ \\
\hline & & Post-test & 3.985 & .562 & \\
\hline \multirow{2}{*}{$\begin{array}{l}\text { Defining } \\
\text { problems }\end{array}$} & & Pre-test & 4.014 & .521 & -1.234 \\
\hline & & Post-test & 4.100 & .539 & \\
\hline \multirow{2}{*}{$\begin{array}{l}\text { Finding } \\
\text { solutions }\end{array}$} & & Pre-test & 3.914 & .575 & $-2.590 *$ \\
\hline & & Post-test & 4.128 & .490 & \\
\hline \multirow{2}{*}{$\begin{array}{l}\text { Evaluating the } \\
\text { solution }\end{array}$} & & Pre-test & 3.600 & 627 & -1.552 \\
\hline & & Post-test & 3.785 & .609 & \\
\hline \multirow{2}{*}{$\begin{array}{l}\text { Implementing } \\
\text { the plan }\end{array}$} & & Pre-test & 3.871 & .546 & $-2.750 * *$ \\
\hline & & Post-test & 4.028 & .468 & \\
\hline \multirow{2}{*}{$\begin{array}{l}\text { Creative Problem } \\
\text { Solving (CPS) }\end{array}$} & & Pre-test & 3.852 & .543 & .830 \\
\hline & & Post-test & 3.720 & .553 & \\
\hline \multirow{2}{*}{$\begin{array}{l}\text { Identifying } \\
\text { problems }\end{array}$} & CG & Pre-test & 3.911 & .608 & 1.158 \\
\hline & & Post-test & 3.838 & .503 & \\
\hline Defining & & Pre-test & 3.926 & .565 & .796 \\
\hline
\end{tabular}




\begin{tabular}{lllll} 
problems & Post-test & 3.838 & .586 & \\
Finding & Pre-test & 3.735 & .593 & .674 \\
solutions & Post-test & 3.514 & .773 & \\
Evaluating the & Pre-test & 3.823 & .601 & 1.737 \\
solution & Post-test & 3.852 & .469 & \\
Implementing & Pre-test & 3.911 & .608 & .274 \\
the plan & Post-test & 3.838 & .503 & \\
\hline
\end{tabular}

$* p<.05, * * p<.01$

\subsection{Analysis of Covariance (ANCOVA)}

A One-way ANCOVA was then applied to verify the statistically significant difference between the EG and the CG in the post-test controlling for the pre-test. The overall CPS was not significantly different between the EG and CG $(F=2.628, p>.05)$; however, the dimensions of CPS, including identifying problems, finding solutions and evaluating the solution, were significantly different. The results of these three variables can be seen in Tables 4 and 5. A preliminary examination of the homogeneity of the regression coefficients in the groups showed no significant difference between the EG and the CG in the pre-test in the dimensions of identifying problems $(F=.547$, $p=.462>.05)$, finding solutions $(F=2.903 p=.093>.05)$, and evaluating the solution $(F=.845, p=.361>.05)$, indicating no significant effect on the two groups in the post-test after scheming the pre-test. The covariates were subjected to a further analysis afterward and the result of the homogeneity of variation test of the dimensions of identifying problems $(F=.534, p=.467>.05)$, finding solutions $(F=1.996, p=.162>.05)$, and evaluating the solution $(F=.859$, $p=.358>.05)$ demonstrated that the variation was the same for the two groups with the same value. The result of the final analysis of the covariates showed that there was a significant effect on the two groups in terms of identifying problems $[F(1,64)=7.135, p=.01]$, finding solutions $[F(1,64)=1.379, p<.05]$, evaluating the solution $[\mathrm{F}(1,64)=$ $2.157, \mathrm{p}<.05]$ in the post-test, indicating that the EG's ability to identify problems, find solutions and evaluate solutions was significantly better than the CG's.

Consequently, a one-way ANCOVA was applied to determine the statistical differences in both groups' ability to define problems, implement the plan, and their overall ability. There was no significant difference between the EG and CG in terms of their ability to define problems $[F(1,64)=3.789, p>.05]$, implement the plan $[F(1,64)=.2 .618$, $p>.05]$, and their overall ability $[F(1,64)=2.628, p>.05]$. However, there were significant differences between the two groups in terms of the three skills of CPS and the score of the EG was higher than that of the CG. Hence, the PBL intervention had succeeded in enhancing the ability of the students in the experimental group to identify problems, find solutions, and evaluate the solution, unlike those students in the CG.

Table 4. Descriptive analysis of CPS between two groups

\begin{tabular}{lllll}
\hline Variables & Groups & $\mathrm{M}$ & $\mathrm{SD}$ & $\mathrm{N}$ \\
\hline \multirow{4}{*}{ Identifying problems } & EG & 3.985 & .562 & 35 \\
& $\mathrm{CG}$ & 3.718 & .567 & 34 \\
& Overall & 3.858 & .576 & 69 \\
Finding solutions & $\mathrm{EG}$ & 4.128 & .490 & 35 \\
& $\mathrm{CG}$ & 3.843 & .601 & 34 \\
& Overall & 3.992 & .560 & 69 \\
Implementing the & EG & 3.785 & .609 & 35 \\
plan & $\mathrm{CG}$ & 3.484 & .787 & 34 \\
& Overall & 3.641 & .711 & 69 \\
\hline
\end{tabular}


Table 5. Summary of one way ANCOVA of CPS

\begin{tabular}{lccccc}
\hline & \multicolumn{5}{c}{ Identifying problems } \\
Source & $S S$ & $d f$ & $M S$ & $F$ & $p$ \\
\hline Pre-test & 5.260 & 1 & 5.260 & 21.789 & .000 \\
Classes & 1.723 & 1 & 1.723 & 7.135 & $.010^{* *}$ \\
Error & 15.451 & 64 & .241 & & \\
Total & 21.903 & 66 & & & \\
\hline & \multicolumn{5}{c}{ Finding solutions } \\
\hline Source & $S S$ & $d f$ & $M S$ & $F$ & $p$ \\
Pre-test & 2.245 & 1 & 2.245 & 8.379 & .005 \\
Classes & 1.379 & 1 & 1.379 & 5.149 & $.027^{*}$ \\
Error & 17.145 & 64 & .268 & & \\
Total & 20.746 & 66 & & & \\
\hline & \multicolumn{7}{c}{ Evaluating the solution } \\
\hline Source & $S S$ & $d f$ & $M S$ & \\
Pre-test & 4.965 & 1 & 4.965 & 11.804 & .001 \\
Classes & 2.157 & 1 & 2.157 & 5.127 & $.027^{*}$ \\
Error & 26.920 & 64 & .421 & & \\
Total & 33.403 & 66 & & \\
\hline$* p<.05, * * p<.01$ & & & & \\
\hline
\end{tabular}

\section{Discussion}

The aim of this study was to investigate that whether or not college students' CPS was enhanced by using PBL. A quasi-experimental design was applied in order to answer two research questions. The first was whether or not PBL could be effectively applied to enhance master students' CPS in an education management course. This question was answered in the affirmative by the research results, which showed that the CPS of the students in the experimental group had significantly improved after the PBL intervention, especially in terms of their ability to identify problems, find solutions, and evaluate the solution. This finding corresponds to that of previous studies that also demonstrated the positive effect of PBL on developing students' high-order thinking, including creativity, critical thinking, and problem solving (Tsybulsky \& Muchnik-Rozanov, 2019; Chu et al., 2017; Häkkinen et al., 2017). More specifically, team project work and students' commitment to it could successfully process CPS (Sousa et al., 2013). While Laio et al. (2014) found that there were differences in CPS between genders, no such difference was found in this study. This result is supported by Senyuva et al. (2014), who also found that there was no statistical difference between genders before and after PBL training.

The second question was in relation to the key CPS skills that were considerably better after the PBL intervention. This question was answered by the finding that students' ability to identify problems, find solutions and evaluate the solution was enhanced effectively with PBL, but there was no difference between the genders. However, Laio et al. (2014) found that the ability of male students to identify problems, define solutions and evaluate the solution was significantly enhanced, but the female students better developed their ability to find solutions and implement the plan. It was found in this study that the students' ability to define problems and implement the plan did not improve after the intervention. However, Sousa et al. (2013) state that this is not important, since it may remind them to renew their focus on defining problems. Since the tasks to be implemented by the sub-teams are listed in the action plan, it is easy for the team members to focus on those tasks and ignore the main problem they are expected to solve. Hence, it is crucial to define milestones for the project to be certain that the teams meet up regularly so that tasks and aims can be reframed. In the current study, the small groups only met up in the scheduled classes, but did not arrange additional gatherings during the week. In some cases, team members only worried about completing their tasks 
without exchanging information with other members; therefore, no work was reviewed by other team members. A lack of team dialogue and effective reviews of other group members' work are obstacle to progress the implementation of the plan (Pinho-Lopes \& Macedo, 2014).

\section{Conclusion}

This study aimed to apply project-based learning to develop the creative problem-solving ability of master students in the field of Education Management. Compulsory team projects were implemented based on a quasi-experimental design and the statistical results were validated using theoretical solutions to the problems. Sustained evaluations of the values of convinced quantities were provided. The goal to develop the students' creative problem-solving skills was achieved and questionnaires were applied both before and after the intervention to assess its impact.

Based on the numerical results, the active project-based learning was useful and effective in facilitating and promoting the production of knowledge and in developing the students' creative problem-solving ability (Pinho-Lopes \& Macedo, 2014), especially in terms of identifying problems, finding solutions and evaluating the solution. Although the project design and development were challenging, the master students coped with the difficulties and aimed to enrich their personal knowledge and skills ( $\mathrm{Wu}$ and $\mathrm{Wu}, 2020)$. Evidence from this study demonstrated that the project-based learning approach actively enhanced students' higher-order thinking skills more successfully than the traditional lecture-based instruction (Chen et al., 2020; Khan et al., 2017). Hence, it can be concluded that the project-based learning approach was effective in enhancing the creative problem-solving ability of postgraduate students in the education management field, specifically in the dimensions of identifying problems, finding solutions and evaluating the solution.

\section{Implications}

This research makes an empirical contribution to those universities, academics, educators, instructors and researchers, particularly in postgraduate programmes in the management field, who value the application of the project-based learning method to effectively develop master students' creative problem-solving skills. It has been stated that the central idea of pedagogy has shifted to student-centred learning (Gumuseli \& Eryilmaz, 2011) and leadership practice is orientated toward pedagogical dynamics (Chen et al., 2020). However, this research has several limitations, the first of which is that online learning is the current trend (Upreti, 2020); hence, it is suggested that future studies of PBL should be based online with a flipped classroom model. Secondly, the participants in this study were postgraduate students in education management; hence, future researchers may investigate the effect of PBL on different levels of college students in various programmes ( $\mathrm{Wu} \& \mathrm{Wu}, 2020)$. The last limitation is that the only instrument used to measure the outcome of this study was a questionnaire; therefore, other strategies of assessment, including students' feedback and academic performance (Pinho-Lopes \& Macedo, 2014) could be applied to future research.

\section{Note}

Note 1. The programme offers an extensive training in education and management courses. After the accomplishment, the students will have an advanced knowledge of modern management, leadership, pedagogical issues and the changes of the educational sector.

\section{References}

Anderson, L. W., Sosniak, L. A., \& Bloom, B. S. (1994). Bloom's Taxonomy: A Forty-Year Retrospective. Chicago (IIl.): University of Chicago press. https://lib.ugent.be/catalog/rug01:000925762

Arvanitakis, J., \& Hornsby, D. J. (2016). At Universities Redundant? In J. Arvanitakis, \& D. J. Hornsby (eds.), Universities, the Citizen Scholar and the Future of Higher Education (pp. 7-20). Palgrave Macmillan. https://doi.org/10.1057/9781137538697_2

Ayers, S. J. (1989). Creative Problem Solving in the Classroom [Doctoral dissertation, Texas Tech University]. ERIC. https://eric.ed.gov/?q=CREATIVE+PROBLEM+SOLVING+IN+THE+CLASSROOM\&id=ED317446

Beyer, B. K. (1987). Practical Strategies for the Teaching of Thinking. Allyn and Bacon. https://openlibrary.org/books/OL2373668M/Practical_strategies_for_the_teaching_of_thinking

Bolsunovskaya, L., Phillips, C., Korotchenko, T., Matveenko, I., Strelnikova, A., \& Ulyanova, O. (2015). Project-based method in teaching foreign language for specific purposes. Procedia - Social and Behavioral Sciences, 215, 176-180. https://doi.org/10.1016/j.sbspro.2015.11.615

Bonikowska, A., Green, D. A., \& Riddell, W. C. (2008). Literacy and the labour market: cognitive skills and 
immigrant earnings (catalogue no. 89-552-M no. 020). Survey. International Adult Literacy. https://citeseerx.ist.psu.edu/viewdoc/download?doi=10.1.1.526.1111\&rep=rep1\&type=pdf

Chen, P., Chang, Y., \& You, X. (2020). Development of Problem Solving Confidence to Chinese International Graduate Students of Educational Management in Thailand by using Active Learning [Paper presentation]. Bangkok, Thailand. The 2nd China-ASEAN International Conference 2020 \& The 2nd International Conference on Tourism, Business, \& Social Sciences 2020 - Insight to China and ASEAN's Wellness, Tourism, \& Innovation. https://doi.org/10.6947/caicictbs.202004.0031.

Chen, P., Tolmie, A., \& Wang, H. (2017). Growing the critical thinking of schoolchildren in Taiwan using the Analects of Confucius. International Journal of Educational Research, 84, 43-54. https://doi.org/10.1016/j.ijer.2017.02.002

Chiang, C. L., \& Lee, H. (2016). The effect of project-based learning on learning motivation and problem-solving ability of vocational high school students. International Journal of Information and Education Technology, 6(9), 709-712. https://doi.org/10.7763/IJIET.2016.V6.779

Chiang, C. L., \& Lee, H. (2016). The effect of project-based learning on learning motivation and problem-solving ability of vocational high school students. International Journal of Information and Education Technology, 6(9), 709-712. https://doi.org/10.7763/IJIET.2016.V6.779

Chu, S. K. W., Reynolds, R. B., Tavares, N. J., Notari, M., \& Lee, C. W. Y. (2017). 21 st Century Skills Development through Inquiry-Based Learning. Springer. https://doi.org/10.1007/978-981-10-2481-8

English, M. C., \& Kitsantas, A. (2013). Supporting student self-regulated learning in problem and project-based learning. Interdisciplinary Journal of Problem-Based Learning, $7(2), \quad 128-150$. https://doi.org/10.7771/1541-5015.1339

Fleming, D. S. (2000). A Teacher's Guide to Project-Based Learning. AEL. https://files.eric.ed.gov/fulltext/ED469734.pdf

García-Martínez, I., Díaz-Delgado, M. A., \& Ubago-Jiméne, J. L. (2018). Educational leadership training, the construction of learning communities. A systematic review. Social Sciences, 7(267), 1-13. https://doi.org/10.3390/socsci7120267

Gumuseli, A. I., \& Eryilmaz, A. (2011). The Measurement of Collaborative School Culture (CSC) on Turkish Schools. New Horizons in Education, 59, 13-26. https://files.eric.ed.gov/fulltext/EJ955530.pdf

Häkkinen, P., Järvelä, S., Mäkitalo, K., Ahonen, A., Näykki, P., \& Valtonen, T. (2017). Preparing teacher-students for twenty-first-century learning practices (PREP 21): a framework for enhancing collaborative problem-solving and strategic learning skills. Teachers and Teaching, 23(1), 25-41. https://doi.org/10.1080/13540602.2016.1203772

Hârtescu, I. (2014). Providing technology support for project-based learning [Paper presentation]. The International Scientific Conference e-Learning and Software for Education, 3. Bucharest. http://dx.doi.org/10.12753/2066-026X-14-175

Hayes, J. R. (1989). The Complete Problem Solver (2nd ed.). Routledge. https://www.routledge.com/The-Complete-Problem-Solver/Hayes/p/book/9780805803099

Isaksen, S. G., \& Treffinger, D. J. (1985). Creative Problem Solving: The Basic Course. Bearly. https://www.semanticscholar.org/paper/Creative-Problem-Solving\%3A-The-Basic-Course-Isaksen-Treffinger/1 4b261b5357fb3043b8470e872733d3747c98a06

Isaksen, S. G., Dorval, K. B., \& Treffinger, D. J. (2000). Creative Approaches to Problem Solving (2nd ed.). Kendall/Hunt

Isaksen, S. G., Dorval, K. B., \&Treffinger, D. J. (1994). Creative Approaches to Problem Solving. Kendall/Hunt.

Khan, A., Egbue, O., Palkie, B., \& Madden, J. (2017). Active learning: engaging students to maximize learning in an online course. Journal of e-Learning, 15(2), 107-115. https://files.eric.ed.gov/fulltext/EJ1141876.pdf

Klegeris, A., McKeown, S. B., Hurren, H., Spielman, L. J., Stuart, M., \& Bahniwal, M. (2016). Dynamics of undergraduate student generic problem-solving skills captured by a campus-wide study. High Education, 74(5), 877-896. https://doi.org/10.1007/s10734-016-0082-0

Krajcik, J., Blumenfeld, P., Marx, R., \& Soloway, E. (1994). A collaborative model for helping middle grade science 
teachers learn project-based instruction. The Elementary School Journal, 94(5), 483-497. https://doi.org/10.1086/461779

Laio, C., Li, C., \& Xu, Z. (2014). A study on innovation and problem solving capabilities of accreditation of e-learning course "creative problem solving" with App in i-HO cloud [Paper presentation]. Taiwan. The 2014 Conference of Distance Learning for Higher Education in Taiwan. https://ace.moe.edu.tw/events/seminar_2014_book

Larkin, H., \& Richardson, B. (2013). Creating high challenge/high support academic environments through constructive alignment: student outcomes. Teaching in Higher Education, 18(2), 192-204. https://doi.org/10.1080/13562517.2012.696541

Loyens, S. M. M., Kirschner, P. A., \& Paas, F. (2012). Problem-based learning. In K. R. Harris, S. Graham, T. Urdan, A. G. Bus, S. Major, \& H. L. Swanson (Eds.), APA handbooks in psychology®. APA educational psychology handbook, Vol. 3. Application to learning and teaching (pp. 403-425). American Psychological Association. https://doi.org/10.1037/13275-016

Meo, S. A. (2014). Undergraduate medical student's perceptions on traditional and problem based curricula: pilot study. The Journal of the Pakistan Medical Association, 64(7), 775-779. https://pubmed.ncbi.nlm.nih.gov/25255585/

Munyai, K. (2016). Design thinking: A methodology towards sustainable problem solving in higher Education in South Africa [Paper presentation]. The International Conferences on Internet Technologies \& Society (ITS), Education Technologies (ICEduTECH), and Sustainability, Technology and Education (STE), Melbourne, Australia, https://files.eric.ed.gov/fulltext/ED571612.pdf

Nordstrom, K., \& Korpelainen, P. (2011). Creativity and inspiration for problem solving in engineering education. Teaching in Higher Education, 16(4), 439-450. https://doi.org/10.1080/13562517.2011.560379

Osborn, A. F. (1963). Applied Imagination: Principles and Procedures of Creative Problem-Solving (3rd ed.). Scribner's Sons.

Parnes, S. J. (1967). Creative Behavior Workbook. Scribner's Sons.

Pinho-Lopes, M., \& Macedo, J. (2014). Project-based learning to promote high order thinking and problem solving skills in geotechnical courses. International Journal of Engineering Pedagogy, 4(5), 20-27. https://doi.org/10.3991/ijep.v4i5.3535

Puccio, G. J., Murdock, M. C., \& Mance, M. (2007). Creative Leadership: Skills That Drive Change (2nd ed.). Sage. https://us.sagepub.com/en-us/nam/creative-leadership/book234210

Puccio, G. J., \& Cabra, J. F. (2008). Creative Problem Solving: Past, Present and Future. Routledge. https://doi.org/10.4324/9780203888841

Senyuva, E., Kaya, H., \& Bodur, G. (2014). Effect Social Skills of Nursing Students of the Project Based Teaching Methods. Procedia - Social and Behavioral Sciences, 152, 393-398. https://doi.org/10.1016/j.sbspro.2014.09.218

Sousa, F., Monteiro, I., Walton, A. P., \& Pissarra, J. (2013). Learning from failure: a case study on creative problem solving. Procedia - Social and Behavioral Sciences, 75, 570-580. https://doi.org/10.1016/j.sbspro.2013.04.062

Thomas, J. W., \& Mergendoller, J. R. (2001). Managing Project-Based Learning: Principles from the Field. Buck Institute for Education. http://citeseerx.ist.psu.edu/viewdoc/download?doi=10.1.1.532.3730\&rep=rep1\&type=pdf

Tsybulsky, D., \& Muchnik-Rozanov, Y. (2019). The development of student-teachers' professional identity while team-teaching science classes using a project-based learning approach: A multi-level analysis. Teaching and Teacher Education, 79, 48-59. https://doi.org/10.1016/j.tate.2018.12.006

Upreti, G. (2020). 7 reasons why online learning is the next trend in education. e-Learning Industry. https://elearningindustry.com/reasons-why-online-learning-is-next-trend-in-education

Vidal, R. V. V. (2009). Creativity for problem solvers. AI \& Society, 23, 409-432. https://doi.org/10.1007/s00146-007-0118-1

Visone, J. D. (2018). The development of problem-solving skills for aspiring educational leaders. Journal of 
Leadership Education, 17(4), 35-53. https://doi.org/10.12806/V17/I4/R3

$\mathrm{Wu}$, Ting-Ting \& Wu, Yu-Tzu. (2020). Applying project-based learning and SCAMPER teaching strategies in engineering education to explore the influence of creativity on cognition, personal motivation, and personality traits. Thinking Skills and Creativity, 35, 100631. https://doi.org/10.1016/j.tsc.2020.100631

Zhang, Y., Chen, P., \& Yu, T. (2019). Reading and Writing Learning Strategies for Low English Proficiency Students at a Private University in China. International Journal of Higher Education, 8(3), 214-225. https://doi.org/0.5430/ijhe.v8n3p214

\section{Copyrights}

Copyright for this article is retained by the author(s), with first publication rights granted to the journal.

This is an open-access article distributed under the terms and conditions of the Creative Commons Attribution license (http://creativecommons.org/licenses/by/4.0/). 